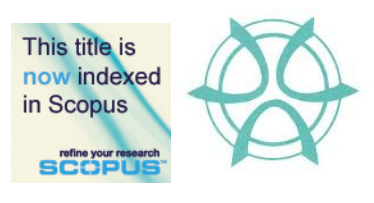

PLANNING MALAYSIA:

Urban Planning and Local Governance

Volume III (2014), Page 67- 80

\title{
HISTORICAL INFLUENCES TO PRESENT LEGAL SETTING OF PLANNING LAW IN MALAYSIA
}

\author{
Azila Ahmad Sarkawi ${ }^{1}$ and Muhammad Faris Abdullah ${ }^{2}$ \\ ${ }^{1 \& 2}$ Kulliyyah of Architecture and Environmental Design \\ INTERNATIONAL ISLAMIC UNIVERSITY MALAYSIA
}

\begin{abstract}
Malaysia is a federation of thirteen states and three federal territories. Thus, it is a challenge to achieve uniformity of laws among the states. Presently, there are four sets of planning laws applicable in Malaysia. This paper looks at the historical factors that led to the non-uniformity of planning law in Malaysia. By using historical research methodology, this study found that the emergence of individual states back in the year $1400 \mathrm{AD}$ is among the historical factors contributing to this non-uniformity of law. Additionally, the colonisation and the British influence over Malay Peninsula and the Borneo region, the formation of the Malaya Federation and the creation of federal territories also have strong implications in terms of administration and law uniformity. Despite the states eventually united under the essence of federation in 1963, this did not entail uniformity of laws among them. Additionally, states also have no obligation to adopt laws enacted by the Federal Government. Nevertheless, efforts to harmonise planning in the country have been undertaken. These include the amendment of planning laws and the establishment of national level planning committee.
\end{abstract}

Keyword: planning law, planning structure, constitution, federation, states.

\footnotetext{
${ }^{1}$ Associate Professor at Department of Urban and Regional Planning. Email: azila.sarkawi@gmail.com

${ }^{2}$ Assistant Professor at the Department of Urban and Regional Planning. Email: mfaris@iium.edu.my
} 
Azila Ahmad Sarkawi and Muhammad Faris Abdullah

Historical Influences to Present Legal Setting of Planning Law in Malaysia

\section{INTRODUCTION}

Malaysia is a federation made up of thirteen States and three Federal Territories. The States are Johor, Kedah, Kelantan, Melaka, Negeri Sembilan, Pahang, Perak, Perlis, Pulau Pinang, Sabah, Sarawak, Selangor and Terengganu. Meanwhile, the three Federal Territories are Kuala Lumpur, Labuan and Putrajaya. Being a Federation, Malaysia subscribes to the essence of federalism that is '...the establishment of a single political system, within which, general and regional governments are assigned to coordinate authority such that neither level of government is legally or politically subordinate to the other" (Watts, 1966:13). As such, the States Government are not obliged to adopt laws enacted by the Federal Government. This partly contributed to the non-uniformity of planning laws in Malaysia. Presently, there are four sets of planning law applicable to different parts of Malaysia.

This study adopted historical methodology to examine historical events and to determine their influences towards planning law scenario in Malaysia. Historical methodology can be described as method to objectively and systematically identify and evaluate evidence to obtain facts and to summarily explain the past happenings. Secondary data were used throughout the study.

\section{DIFFERENT SETS OF PLANNING LAW COVERAGE IN MALAYSIA}

The four sets of planning law applicable in Malaysia presently are:

i. $\quad$ Town and Country Planning Act 1976 (Act 172);

ii. $\quad$ Federal Territory (Planning) Act 1982 (Act 267);

iii. Town and Country Planning Ordinance 1950 (Cap. 141); and

iv. Sarawak Land Code (Cap. 81 [1958 Ed.]).

Figure 1 below shows the coverage of each set of the planning law. Town and Country Planning Act 1976 (Act 172) is applicable to all States in the Peninsular Malaysia. Meanwhile, all the Federal Territories adopted the Federal Territory (Planning) Act 1982 (Act 267). In Sabah, the State Government adopted its own Town and Country Planning Ordinance 1950 (Cap. 141). Similarly, the State Government of Sarawak also enacted its own law pertaining to matters including planning, which is the Sarawak Land Code (Cap. 81). 

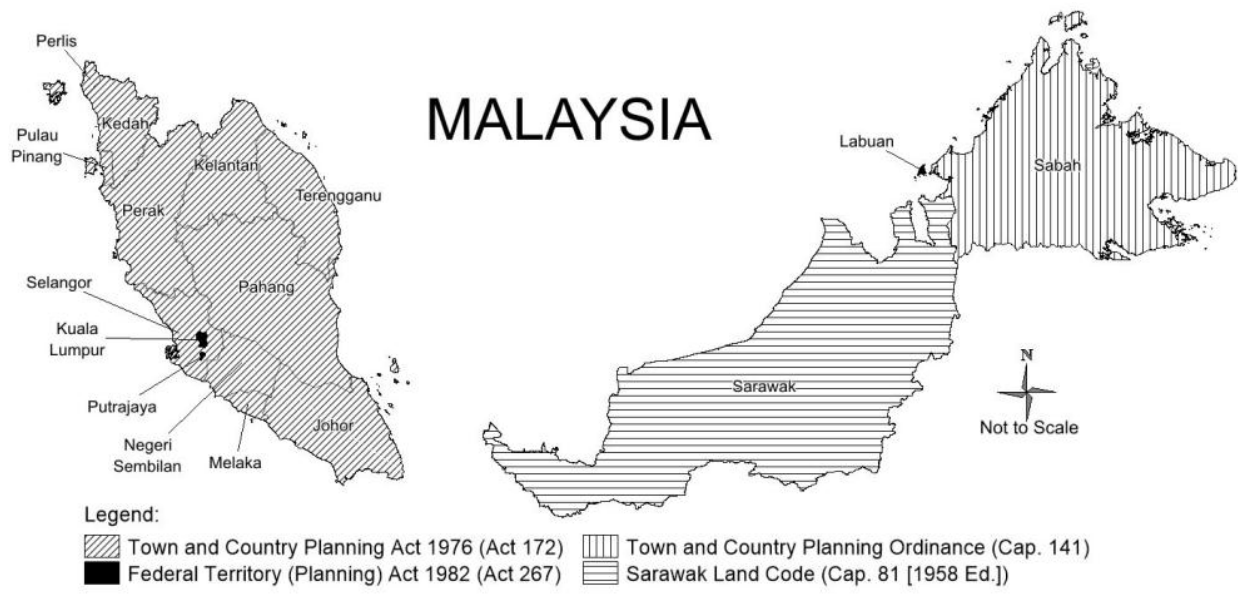

Figure 1: Different sets of planning law coverage in Malaysia

\section{HISTORICAL INFLUENCES TO PRESENT TOWN AND COUNTRY PLANNING LEGAL SETTING}

This study has found that the present situation where there exists a different set of planning law being applicable within Malaysia was partly influenced by the history of the development of the country. Table 1 below outlines important historical events from $1400 \mathrm{AD}$ to 1965 that have partly influenced the present legal setting in Malaysian town and country planning.

Table 1: Important historical events that influenced the present legal setting in Malaysian planning.

\begin{tabular}{|l|l|}
\hline \multicolumn{1}{|c|}{ Year } & \multicolumn{1}{c|}{ Event } \\
\hline 1400 & Malacca established by Parameswara. \\
\hline 1824 & $\begin{array}{l}\text { British acquired Malacca and formed Straits Settlements with Penang } \\
\text { and Singapore }\end{array}$ \\
\hline $\begin{array}{l}1843- \\
1917\end{array}$ & Sarawak and British North Borneo established incrementally. \\
\hline 1846 & British acquired Labuan. \\
\hline 1874 & $\begin{array}{l}\text { Pangkor Treaty with Perak sets scene for British to extend control } \\
\text { throughout the Malay Peninsula. }\end{array}$ \\
\hline 1896 & Establishment of Federated Malay States (FMS). \\
\hline 1914 & Grouping of Unfederated Malay States (UMS). \\
\hline 1945 & $\begin{array}{l}\text { Sarawak and British North Borneo became the responsibility of the } \\
\text { British. }\end{array}$ \\
\hline 1946 & British established Malayan Union. \\
\hline
\end{tabular}


Azila Ahmad Sarkawi and Muhammad Faris Abdullah

Historical Influences to Present Legal Setting of Planning Law in Malaysia

\begin{tabular}{|l|l|}
\hline 1948 & Federation of Malaya formed. \\
\hline 1957 & Independence granted and Malaya formed. \\
\hline 1963 & $\begin{array}{l}\text { Malaysia formed through the unification of Malaya, Singapore, Sabah } \\
\text { and Sarawak with Tunku Abdul Rahman elected Prime Minister. }\end{array}$ \\
\hline 1974 & Kuala Lumpur became a federal territory. \\
\hline 1984 & Labuan became a federal territory. \\
\hline 2001 & Putrajaya became a federal territory. \\
\hline
\end{tabular}

Source: Adapted from Church, 1999 as cited in Bruton, (2007).

Historically, Malacca was found in 1400 AD by Parameswara. From a traditional fishing village, Malacca grew into an international trading port and enjoyed economic prosperity and had become '...new standard for Malays achievement' (Andaya \& Andaya, 2001:78). One hundred years on, in 1511, Malacca fell to the Portuguese who aimed to control maritime trade throughout the region. This led to the setting up of the Kingdom of Johor by Sultan Alauddin Riayat Shah, an heir to the Malacca sultanate. Later, with the assistance of the Dutch in Java, Johor ousted the Portuguese from Malacca. This put Malacca under Dutch influence through its United Netherlands Chartered East India Company.

At the same time, the British were also eyeing on Malacca to be under its sphere of influence. The British had already acquired Penang in 1786 and Singapore in 1819. Thus, in 1824, following the Anglo-Dutch Treaty, Malacca and the Malay Peninsula were transferred under the British sphere of influence.

However, British sphere of influence was restricted as far as the northern states of the Peninsula were concerned. This is because, during Malacca's territorial expansion back in the early $15^{\text {th }}$ century, the northern Malay states of Kelantan, Terengganu, Perlis and Kedah acknowledged Siam as overlord and Malacca's influence was only felt here towards the end of the $15^{\text {th }}$ century (Suhana, 1999; Rutter, 1989). After the fall of Malacca in 1511 and the decline of Johor in 1699, other states in the Peninsular emerged as individual states which generally recognized Siam as overlord and sent the 'golden flower' (bunga mas) as a sign of overlordship. This continued until the 1909 treaty between the British and Siam that transferred the suzerainty of Siam over the northern states to the British. These states became the Unfederated Malay States (UMS) under British administration.

The British sphere of influence was not limited to the Peninsula but also extended to the Borneo territories. British involvement in the Borneo region became greater from the 1840s after Sarawak inception as an identifiable political unit. Sarawak owes its inception as a state to the English adventurer, James Brooke (1803-68). The association between 
Britain and the Brookes also helped to reinforce the connection between northwest Borneo and the Malay Peninsula. This connection was important as it also contributed to the inclusion of the Borneo states into Malaysia. By 1846 , British continued to reinforce its influence in the Borneo region by acquiring the island of Labuan (Rozan Yunos, 2008). By 1868, Britain had made clear of her interest in northern Borneo (Sabah), which was now included in the British sphere of influence (Rutter, 1989).

Up to this point, a process which stretched back to a series of conquests of Malacca and British colonisation of the states of the Malay Peninsula had reached its conclusion under the British administrative system. As a result, the Peninsula was divided into the Straits Settlements, the Federated Malay States, the Unfederated Malay States and Borneo, which consisted of three protectorates including Labuan Island. This division of administrative units is shown in Figure 2 below.

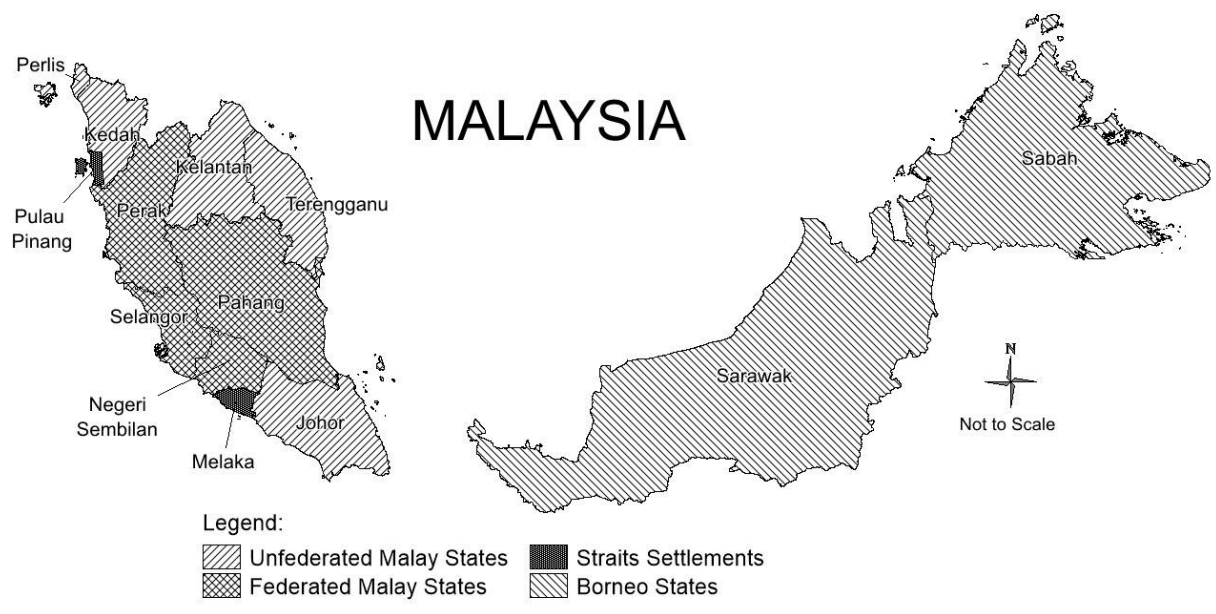

Figure 2: Malaya Administrative Units under British Colonization

In 1946, the British had established the Malayan Union and subsequently the Federation of Malaya in 1948. This paved the way to the independence of Malaya. However, strong connection between Malaya and the Borneo region had led to the formation of Malaysia in 1963. The Malaysia Agreement which was signed in 1963 relinquished British control over Sarawak, North Borneo (Sabah) and Singapore and allow them to join the Federation of Malaysia. Nevertheless, in agreeing to its inclusion into the 
Azila Ahmad Sarkawi and Muhammad Faris Abdullah

Historical Influences to Present Legal Setting of Planning Law in Malaysia

Federation, the North Borneo state proposed a 20-points agreement, which in part requires the provisions of the Federal Constitution with regard to land, forest and local government do not apply in the state. Hence, planning also remains within the domain of the state to regulate.

In more recent times, several areas of the states have also been handed over to the Federal Government of Malaysia to administer. Kuala Lumpur, the capital of Malaysia, became a federal territory in 1974. Meanwhile, Labuan Island became the second federal territory in 1984. The most recent addition to the list of federal territories in Malaysia was in 2001 when Putrajaya, the new Federal Government administrative centre became a federal territory.

These historical events, especially the colonisation and the British influence over Malay Peninsula and the Borneo region, the formation of the federation and the 20-point agreement, and the creation of federal territories have strong implications in terms of administration and law uniformity. As a result, at present time, each state in Malaysia has no obligation to adopt the laws enacted by the Federal Government. In other words, it is the state legislatures' discretion to adopt federal laws to be operated in the state. In the circumstance that federal law is to be adopted by the state, it will be gazetted as state law ${ }^{1}$. Additionally, when land is under state jurisdiction as stipulated in the State List of the Federal Constitution, it inevitably affects the development planning process in Malaysia, in terms of final approvals of land matters ${ }^{2}$.

Undeniably this historical account has some legal and administrative impact on current planning practice in Malaysia as affirmed by Bruton (2007:1) when he commented that "Planning in any country is inextricably linked with the history, politics and administrative structure of that country [...] given the different colonial histories of east and west Malaysia they have developed differently and have different systems of planning". This is manifested in the application of different planning laws in different region of Malaysia. As mentioned earlier, the states in the Peninsular (West) Malaysia apply the Town and Country Planning Act 1976 (Act 172), while planning in the federal territories is governed by the Federal Territory (Planning) Act 1982 (Act 267). In the meantime, states in East Malaysia (Sabah and Sarawak) have their own planning laws.

\footnotetext{
${ }^{1}$ Section 1 (2) of the TCPA 1976; "subject to subsection (3), this Act shall come into operation in a State on a date or dates to be appointed by the State Authority, with the concurrence of the Minister, by notification in the State Gazette"

${ }^{2}$ Refer to Ninth Schedule, State List of the Federal Constitution
} 
PLANNING MALAYSIA

Urban Planning and Local Governance

\section{PLANNING STRUCTURE IN MALAYSIA IN THE CONTEXT OF FEDERALISM}

It is worth to look at the planning structure in Malaysia within the Federal Constitution ambit. This is because the current planning system in Malaysia embodied in the Town and Country Planning Act 1976 (TCPA 1976) originated from the Federal Constitution, notably Clause (1) of Article 74, Clause (4) of Article 76 and Clause (2) of Article 80. However, the Act which is meant for the uniformity of law and policy related to proper control of town and country planning is only applicable in Peninsular Malaysia, subject to notification in the State Gazette by the State Authority with the concurrence of the Minister for Housing and Local Government.

The 'Federal Constitution' is the 'supreme law' of the Federation (Article 4). By virtue of the supremacy of the 'Federal Constitution' (hereafter referred to as the Constitution), any law which is inconsistent with the Constitution, to the extent of the inconsistency, is void. Thus, the Constitution is recognised as a written law of the Federation that prescribes the manner in which the governmental system in Malaysia is carried out. Furthermore, it confers the legislative power to the Federal Government and the State Government, and the Local Government as far as planning is concerned. Accordingly, the planning administration in Malaysia is effectively carried out at these three governmental levels.

The relationship between these three governmental levels is governed by Part VI of the Constitution that spells out the distribution of legislative and executive powers followed by the distribution of the financial burden between Federal and State government. The most important parts of this kind of relationship which affect planning legislation are matters relating to land, national development and the National Council for Local Government that have been spelt out in the subsequent provisions. This distribution of power is further supplemented by the Ninth Schedule of the Constitution where three Lists are set out, namely, the Federal List, the State List and the Concurrent List as shown in Table 2 below. 
Azila Ahmad Sarkawi and Muhammad Faris Abdullah

Historical Influences to Present Legal Setting of Planning Law in Malaysia

Table 2: Federal, State and Concurrent Powers in Malaysia (A simplified scheme based on Arts. 74, 95B and Schs. 9-10)

\begin{tabular}{|c|c|c|}
\hline FEDERAL & STATE & CONCURRENT \\
\hline $\begin{array}{l}\text { External affairs } \\
\text { Defence } \\
\text { Internal security } \\
\text { Civil law } \\
\text { Administration of } \\
\text { justice } \\
\text { Citizenship } \\
\text { Machinery of } \\
\text { government } \\
\text { Finance and taxation } \\
\text { Trade and industry } \\
\text { Shipping } \\
\text { Fisheries } \\
\text { Energy } \\
\text { Transport } \\
\text { Education } \\
\text { Health } \\
\text { Labour and professions } \\
\text { Social security } \\
\text { Aborigines } \\
\text { Water supply, rivers and } \\
\text { canals }\end{array}$ & $\begin{array}{l}\text { State government } \\
\text { Islamic law } \\
\text { Malay custom } \\
\text { Islam } \\
\text { Local government } \\
\text { Land } \\
\text { Riverine fisheries } \\
\text { Forestry } \\
\text { Roads and bridges } \\
\text { Public nuisances } \\
\text { Agriculture } \\
\text { Housing } \\
\text { Malay reservations } \\
\text { Water (so far as not } \\
\text { federalized) } \\
\text { Sabah/ Sarawak } \\
\text { (State) } \\
\text { Native law } \\
\text { Posts } \\
\text { Harbours } \\
\text { Libraries } \\
\text { Immigration }\end{array}$ & $\begin{array}{l}\text { Planning } \\
\text { Soil erosion } \\
\text { Scholarship } \\
\text { Public health } \\
\text { Social welfare } \\
\text { National parks and } \\
\text { wildlife } \\
\text { Drainage and irrigation }\end{array}$ \\
\hline
\end{tabular}

Source: Harding (1996).

According to Harding (1996:168) “...the Federal List sets out those subjects on which only Parliament can legislate, and the State List sets out those subjects on which only the State Legislative Assemblies can legislate, while the Concurrent List sets out the subjects on which either may legislate". Any matters not included within these Lists are regarded as State matters (Article 77). Referring to these three lists as shown in Table 2 above, evidently, planning matters come under the 'concurrent list' in which both Federal and State Governments have a legislative power to enact planning law. However, matters pertaining to land are under the State list. 
At the national level, Malaysia practices an integrated system of national development planning (Figure 3). Within this system, a cabinet of ministers is appointed by the King to advise him in the exercise of his functions. It consists of the Prime Minister as chairman and unspecified number of ministers. Three advisory bodies are established under the constitution, which are the National Land Council (NLC), the National Council for Local Government (NCLG) and the National Finance Council (NFC).

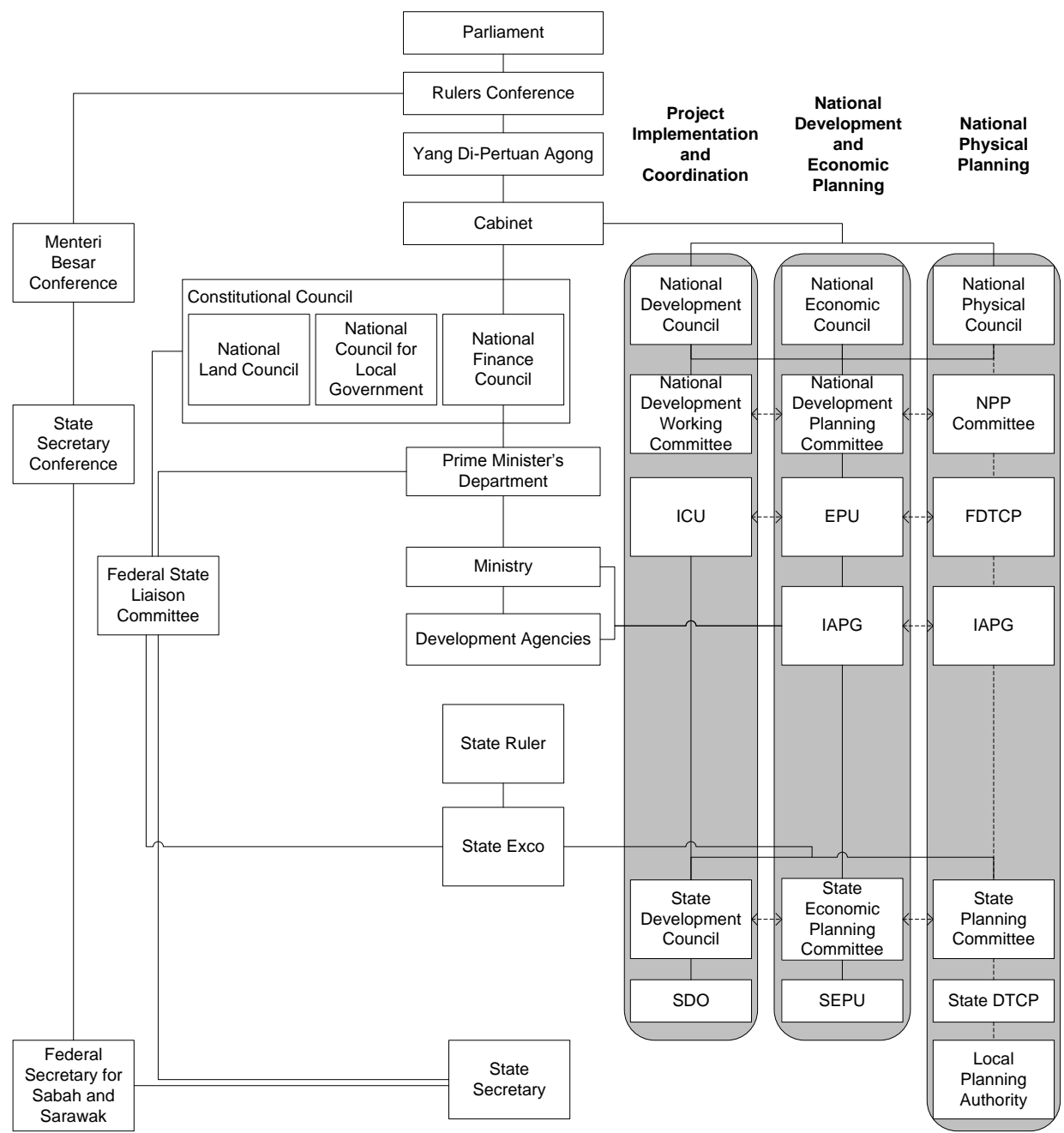

Figure 3: Integrated National Development Planning

Source: Adapted from Bruton (2007) 
Azila Ahmad Sarkawi and Muhammad Faris Abdullah

Historical Influences to Present Legal Setting of Planning Law in Malaysia

This integrated national development planning system is simplified by the diagram below (Figure 4) focusing on hierarchical structure of town and country planning for socio-economic, and physical planning and development in Malaysia.

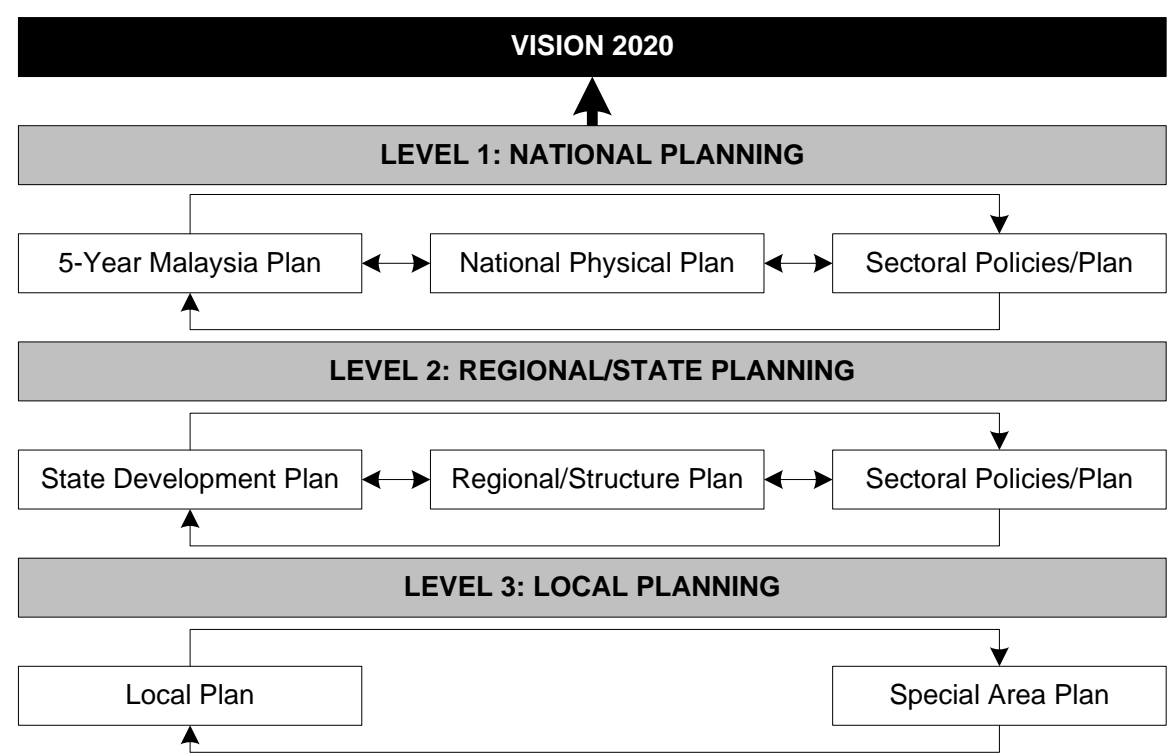

Figure 4: Malaysia: National Development Planning Framework after 2001

Source: Adapted from Nur Sallehi Kassim \& Islam (2006)

In the Peninsular Malaysia, the TCPA 1976 was amended in 2001 to overcome the lack of coordination of planning policies among states and between the Federal and States Government (Taye, 2002:6). It introduces radical changes to the administrative responsibilities of the States and the Federal Government, and strengthened the role of the Federal Government in planning with the following insertions;

i. Provides for the establishment of the National Physical Planning Council (NPPC) chaired by the Prime Minister;

ii. Formally establishes the position of Director-General of Town and Country Planning heading the Federal Town and Country Planning Department;

iii. Makes provision for the establishment of regional planning committees for region that consist of an area situated in two or more states; 
iv. Amends the development control system to require that the state committee seek advice of the NPPC on application for new townships with a population exceeding 10,000 or covering an area of more than 100 hectares or both; a construction of any major infrastructure or utility; and developments affecting hill tops or hill slopes in environmentally sensitive areas;

v. The National Physical Plan prepared by the Director-General of Town and Country Planning is to be translated in State Structure Plan and cascaded to Local Plan.

With regard to Sabah and Sarawak, the Constitution conferred on them greater legislative powers compared to those states in Peninsular Malaysia. Parliament's powers under Article 76A to extend the legislative powers of the States may, in the cases of Sabah and Sarawak, be exercised instead by an order of the Yang di-Pertuan Agong. Parliament's powers to legislate for land and local government do not apply to Sabah and Sarawak, which allows these States exclusive legislative control over these two matters. Although Sabah and Sarawak are represented in the NLC and the NLGC but their representatives may not vote, and they are not obliged to follow any policy laid down by these bodies; this position may, however, be altered by Parliament with the concurrence of the State Government (in relation to the NLC) or the state legislature (in relation to the NLGC). Furthermore, no area in Sabah and Sarawak may be included in a development area proclamation without the consent of the State Government (Harding, 1996:174).

The reasons for this situation may be found by looking back to the history of Sabah and Sarawak prior to and during the formation of Malaysia. These special exclusions and privileges were part and parcel of negotiations during the inclusion of these two states into Malaysia in 1963. From this perspective, Harding (1996:182) tended to conclude that "Malaysia is not a true Federation but rather a quasi-federation, $[\ldots]$ there is no real balance of constitutional power between the States and the Federation [...] the entrenching of special privileges for those States (Sabah and Sarawak) renders Malaysian federalism more complex [...] and that Malaysia is essentially a federation of three units (Malaya, Sabah and Sarawak) rather than thirteen units". 
Azila Ahmad Sarkawi and Muhammad Faris Abdullah

Historical Influences to Present Legal Setting of Planning Law in Malaysia

\section{CONCLUSION}

In short, this paper revealed the historical influences on present planning legal structure in Malaysia. The historical events since 1400AD until the creation of federal territories in more recent times give implications in terms of application of planning law throughout Malaysia. Historically, states were individual kingdoms administered by the Sultans. Throughout time, they were colonised and later formed into a federation, which is Malaysia. Nevertheless, until present day they retain the authority to accept or not to accept Federal laws, which is a result of the negotiation undertaken during the formation of Malaya. Consequently, this has led to the application of different sets of planning law in different regions of Malaysia.

Despite the non-uniformity of planning laws, efforts to harmonise planning throughout the country have been undertaken. These include the amendment to planning laws in order to overcome issues in coordination of planning policies between States and Federal Governments, and the establishment of national level planning committee like the National Physical Planning Council and the National Council for Local Government. Besides national level committees, similar set up of committees at regional level may also need to be put in place in order to further harmonise the planning policies and administration throughout the country. Further research is necessary to determine the impacts of this non-uniformity of planning laws on the administration and implementation of planning and development in the country. 
PLANNING MALAYSIA

Urban Planning and Local Governance

\section{REFERENCES}

Andaya, B.W. \& Andaya, L.Y. (2001). A History of Malaysia. $2^{\text {nd }}$ Edition. Hampshire: Palgrave.

Bruton, M.J. (2007). Malaysia: The Planning of a Nation. Kuala Lumpur: Persatuan Pegawai Perancang dan Desa Malaysia (PERSADA).

Federal Town and Country Planning Department Peninsular Malaysia (2002). Encyclopaedia of Law and Administration of Urban and Regional Planning. Kuala Lumpur: Ministry of Housing and Local Government, Malaysia.

Foziah Johar (1989). An Evaluation of Malaysian Town Planning Legislation. Unpublished Master's Dissertation, Faculty of Law, Newcastle Upon Tyne.

Goh, B.L. (1991). Urban Planning in Malaysia: History, Assumptions and Issues. Selangor: Tempo Publishing.

Grant, M. (1982). Encyclopaedia of Planning law and Practice. London: Sweet \& Maxwell.

Harding, A. (1996). Law, Government and the Constitution in Malaysia. London: Kluwer Law International.

Harding, A. (2003). Planning, environment and development: a comparison of planning law in Malaysia and England. Environmental Law Review, 5, pp. 231-255.

Hishamudin, M. (1995). An essay on the constitutional history of Malaysia. Current Law Journal, 3 (xiv).

Ibrahim, A. \& Ahilemah, J. (1995). The Malaysian Legal System. Kuala Lumpur: Dewan Bahasa dan Pustaka.

Lee, L.M., Mutalip, A.A. and Alip, R. (1990). Town Planning in Malaysia: History and Legislation. Penang: School of Housing, Building and Planning, University Science Malaysia.

Liaw, Y.F. (1976). The Laws of Melaka. The Hague: Martinus, Nijhoff.

Liam, H.K. (1978). The Evolution of the Urban System in Malaysia. Kuala Lumpur: University Malaya.

Nur Sallehi Kassim \& Islam, R. (2006). An integration of multicriteria analysis with GIS in the Malaysian National Physical Plan. Planning Malaysia, 4, pp. 69-82. 
Azila Ahmad Sarkawi and Muhammad Faris Abdullah

Historical Influences to Present Legal Setting of Planning Law in Malaysia

Pillay, S. (1999). The changing faces of administrative law in Malaysia. Malayan Law Journal, 1 (140).

Rozan Yunos (2008). Loss of Labuan: a former Brunei Island. The Brunei Times, $7^{\text {th }}$ September 2008.

Rutter, M. (1989). The Applicable Law in Singapore and Malaysia. Kuala Lumpur: Malayan Law Journal Sdn Bhd.

Suhana, S. A. (1999). Malaysian Legal System. Kuala Lumpur: Malayan Law Journal Sdn Bhd.

Watts. R. L. (1966). New Federations: Experiments in the Commenwealth. Oxford: Clarendon Press. 